\title{
POSTERIOR VERTEBRAL COLUMN RESECTION (PVCR): A SAFE AND EFFECTIVE OPTION TO TREAT KYPHOSIS FROM SPINAL TUBERCULOSIS
}

\author{
RESSECÇÃO DA COLUNA VERTEBRAL POR VIA POSTERIOR (RCVP): OPÇÃO SEGURA E \\ EFICAZ PARA TRATAR CIFOSE POR TUBERCULOSE VERTEBRAL
}

\section{RESECCIÓN DE LA COLUMNA VERTEBRAL POR VÍA POSTERIOR (RCVP): OPCIÓN SEGURA Y EFICAZ PARA TRATAR CIFOSIS POR TUBERCULOSIS VERTEBRAL}

\author{
Plínio Braga linhares Garcia, ${ }^{1}$ Luis Eduardo Carelli Teixeira da Silva, ${ }^{1}$ Alderico Girão Campos de Barros, ${ }^{1}$ Luiz Eduardo Pereira Costa Assis de Almeida ${ }^{1}$ \\ 1. Instituto Nacional De Traumatologia E Ortopedia Jamil Haddad - INTO, Rio de Janeiro/RJ, Brazil.
}

\begin{abstract}
Objective: To evaluate the clinical and radiological results of posterior vertebral column resection (PVCR) for the treatment of kyphosis from spinal tuberculosis. Methods: Retrospective study of a series of 14 cases, 9 female and 5 male, with a mean age of 28 years (1 to 64 ) at the time of surgery, with spinal tuberculosis with mean kyphosis of $56.42^{\circ}\left(2^{\circ}\right.$ to $\left.95^{\circ}\right)$. Results: All patients underwent surgical treatment with PVCR, with a mean number of 2.57 (1 to 6) resected vertebrae and a mean number of instrumented vertebrae of 6.14 (4 to 8 ). The mean kyphosis correction was $64 \%$ after up to one year of follow-up. Prior to surgery, eight patients had signs of spinal cord impairment (ASIA score ranging from $A$ to D), and six did not present any deficit of strength or sensory function (ASIA E). There was no neurological worsening and everyone with deficits improved by at least one degree on the scale. In the postoperative follow-up, bone consolidation was observed in all patients, except one. Among the intra- and postoperative complications, pleurotomy was the most prevalent. Conclusion: Posterior vertebral column resection has proven to be a safe and effective option for the treatment of kyphotic deformity from spinal tuberculosis. Level of evidence IV; Therapeutic studies - Investigation of treatment results.
\end{abstract}

Keywords: Tuberculosis, Spinal; Osteotomy; Neurological Deficit.

\section{RESUMO}

Objetivo: Avaliação dos resultados clínicos e radiológicos da ressecção da coluna vertebral por via posterior (RCVP) no tratamento da cifose por tuberculose vertebral. Métodos: Estudo retrospectivo de uma série de 14 casos, sendo 9 do sexo feminino e 5 do sexo masculino, com média de idade de 28 anos (1 a 64) à época da cirurgia, portadores de tuberculose vertebral, com média de cifose de 56,42 $\left(2^{\circ}\right.$ a $95^{\circ}$ ). Resultados: Todos os pacientes foram submetidos ao tratamento cirúrgico com RCVP, com número médio de 2,57 (1 a 6) vértebras ressecadas e número médio de vértebras instrumentadas de 6,14 (4 a 8). A média de correção da cifose foi de 64\%, com até um ano de seguimento. Antes da cirurgia, oito pacientes apresentavam sinais de sofrimento medular (escore ASIA variando de A a D) e outros seis não apresentavam déficit de força ou sensibilidade (ASIA E). Não houve piora neurológica, e todos os que tinham déficits melhoraram no mínimo um grau na escala. No seguimento pós-operatório, foi evidenciada consolidação óssea em todos os pacientes, exceto um. Dentre as complicações intra e pós-operatórias, a pleurotomia foi a mais prevalente. Conclusões: A ressecção por via posterior mostrou ser uma opção segura e eficaz no tratamento da cifose por tuberculose vertebral. Nível de evidência IV; Estudos terapêuticos - Investigação dos resultados do tratamento.

Descritores: Tuberculose da Coluna Vertebral; Osteotomia; Déficit Neurológico.

\section{RESUMEN}

Objetivo: Evaluación de los resultados clínicos y radiológicos de la resección de la columna vertebral por vía posterior (RCVP) en el tratamiento de la cifosis por tuberculosis vertebral. Métodos: Estudio retrospectivo de una serie de 14 casos, 9 del sexo femenino y 5 del sexo masculino, con promedio de edad de 28 años (1 a 64) en el momento de la cirugía, portadores de tuberculosis vertebral con promedio de cifosis de $56,42^{\circ}\left(2^{\circ}\right.$ a $\left.95^{\circ}\right)$. Resultados: Todos los pacientes fueron sometidos a tratamiento quirúrgico con RCVP, con número promedio de 2,57 (1 a 6) vértebras resecadas y número promedio de vértebras instrumentadas de 6,14 (4 a 8). El promedio de corrección de la cifosis fue de 64\%, con hasta un año de seguimiento. Antes de la cirugía, ocho pacientes presentaban señales de sufrimiento medular (puntuación ASIA variando de A a D), y otros seis no presentaban déficit de fuerza o sensibilidad (ASIA E). No hubo empeoramiento neurológico, y todos los que tenían déficit mejoraron al menos un grado en la escala. En el seguimiento postoperatorio, fue evidenciada consolidación ósea en todos los pacientes, excepto en uno. Entre las complicaciones intra y postoperatorias, la pleurotomía fue la más prevalente. Conclusiones: La resección por vía posterior mostró ser una opción segura y eficaz en el tratamiento de la cifosis por tuberculosis vertebral. Nivel de evidencia IV; Estudios terapéuticos: investigación de los resultados del tratamiento.

Descriptores: Tuberculosis de la Columna Vertebral; Osteotomía; Déficit Neurológico. 


\section{INTRODUCTION}

Tuberculosis, even today, is considered a global public health challenge, and Brazil, according to the World Health Organization (WHO), is one of the priority countries. ${ }^{1}$ According to WHO data, it is estimated that about 6 million new cases occur worldwide and in Brazil, according to the Notifiable Diseases Information System (SINAN), 70,000 new cases emerge annually and 4,500 deaths occur as a result of this disease. ${ }^{2}$

The National Institute of Traumatology and Orthopedics (INTO) is one of the reference hospitals in the Unified Health System (SUS) and frequently receives cases of bone tuberculosis. Bones are a common extrapulmonary tuberculosis site and the spine is the most prevalent location, ${ }^{3}$ corresponding to about $50 \%$ of bone tuberculoses. ${ }^{4,5}$ Although the gold-standard treatment for spinal tuberculosis is prolonged antibiotic therapy, ${ }^{6,7}$ surgical treatment may be the only option in selected cases. Included among these are patients with important neurological deficit, with spinal instability, or with severe or progressive deformity.

There are various modalities of surgical treatment with proven effectiveness for spinal tuberculosis, among them the anterior approach $^{8,9}$ and the combined approach. ${ }^{10,11}$ However, in cases of severe kyphotic deformity vertebrectomy is the routine choice. Since Suk et al. first described the posterior vertical column resection (PVCR), this technique has been shown to be safe, as it presents lower morbidity when compared to vertebrectomy via a combined approach. ${ }^{12}$ PVCR permits circumferential decompression of the dural sac and ample debridement of the devitalized tissues, in addition to promoting significant correction of the kyphotic deformity that often accompanies complicated spinal tuberculosis.

The objective of this study was to evaluate whether posterior vertical column resection is a safe and effective option for the surgical treatment of spinal tuberculosis.

\section{METHODS}

This is a retrospective study of 14 patients with spinal tuberculosis who underwent corrective kyphotic deformity surgery via the PVCR technique at the Instituto Nacional de Traumatologia e Ortopedia Jamil Haddad, during the period from November 2012 to October 2018. All patients were operated by the same surgical team.

Patients with a confirmed microbiological or histopathological diagnosis of spinal tuberculosis, regardless of age, who were submitted to surgical treatment performed using the PVCR technique were included. Patients without a confirmed microbiological or histopathological spinal tuberculosis diagnosis, as well as patients who had undergone PVCR due to other pathologies, such as a tumor or congenital malformation, were excluded.

The patients were analyzed according to age, sex, the vertebral segments affected, neurological status, the magnitude of the kyphotic deformity at diagnosis and at the end of a minimum follow-up of one year, the number of instrumented levels, the number of resectioned vertebrae, the rate of consolidation, and complications. Collection of clinical and demographic data was conducted through analysis of the medical records of the selected patients.

The assessment criterion for the neurological status of the patients was the Frankel scale as modified by ASIA (American Spine Injury Association). ${ }^{13}$ Anteroposterior and lateral panoramic spinal radiographs were analyzed prior to surgery, in the immediate postoperative period, and in outpatient follow-up consultations. The angle of kyphosis was measured by the Cobb method in the lateral radiograph. As most of the patients in our series had some degree of neurological deficit, we decided not to perform the deformity flexibility test. The measurements were taken using Surgimap Spine software (Nemaris Inc, New York, NY). The consolidation rate was evaluated by means of computed tomography performed at least 6 months after the surgery.

In the patients under 10 years of age, due to the small spinal dimensions and attempting to avoid skin complications, posterior cervical spine implants with screws and $3.5 \mathrm{~mm}$ rods were used (Figure 1). In the other patients, conventional thoracolumbar spine fixation materials with screws and $5.5 \mathrm{~mm}$ rods were used.

Following the recommendations of the health authorities and with respect to the social isolation imposed due to the new coronavirus

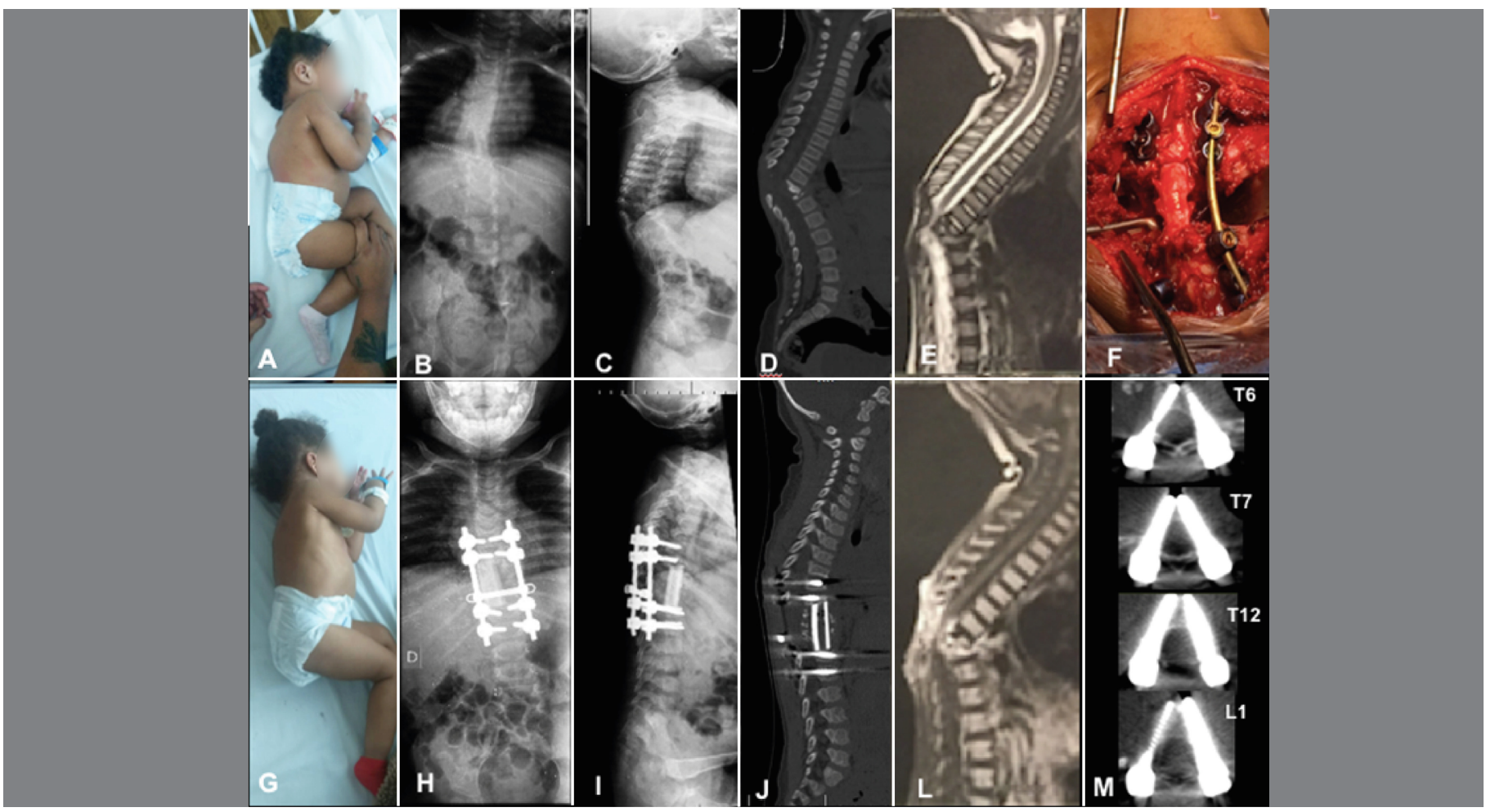

Figure 1. Child, 1 year and 8 months old, strength and sensitivity preserved. Preoperative clinical photo (A), panoramic radiographs (B and C), CT of sagittal reconstruction (D) and MRI of sagittal reconstruction ( $E$ and $L$ ). Intraoperative photo (F). Postoperative clinical photo (G), panoramic radiographs ( $\mathrm{H}$ and $\mathrm{I})$, and sagittal and axial $\mathrm{CT}$ reconstructions ( $\mathrm{J}$ and $\mathrm{M})$. 
(Covid-19) pandemic, we opted to waive the application of the Informed Consent Form (ICF) for this research project. This study was approved by the Institutional Review Board of the Institute as number CAAE: 32791520.9.0000.5273.

\section{Surgical Technique}

The patient, under general anesthesia and multimodal neurophysiological monitorization, is positioned in ventral decubitus on cushions on a radiotransparent table. A medial longitudinal incision is made over the planned instrumentation levels. A subperiosteal medial to lateral dissection with meticulous hemostasis is performed and, at the level planned for the PVCR, the transverse process and 3 or 4 medial centimeters of the corresponding posterior rib are exposed. Facetectomies and bipedicular instrumentation of the levels to be operated, generally 2 to 3 levels above and below the PVCR, are performed. After, fluoroscopic confirmation, a total laminectomy and a costotransversectomy of the levels to be resected are performed. Before starting the resection of the vertebral body, a temporary contralateral rod must be placed as support to prevent translocation and consequent iatrogenic injury to the spinal cord. During this stage, greater care must be taken to avoid the occurrence of pleural injury. Subperiosteal dissection of the vertebral body is initiated and directed anteriorly from the lateral faces of this body. Malleable retractors are used to protect the pleura and large vessels during this maneuver. During the dissection and exposition of the lateral wall of the vertebral body, hemostasis must be meticulous to prevent lesion of the segmental vessels. The vertebral body and the intervening discs are removed. To complete the resection, the temporary fixation rod is moved to the other side and the remaining contralateral vertebral body is resected in the same way. Correction of the deformity is accomplished by in situ modelling of the rods and exchanging the hypomodeled provisionary rods for the desired form, one by one. To prevent an inadvertent distraction of the spinal cord and neural elements, the spine must initially be shortened, with light compression over the resected gap. After the correction is achieved, the temporary rods are substituted one by one by the definitive rods, thus preventing loss of correction. The remaining anterior gap should be filled with autologous bone graft contained in a titanium cage. Anterior or circumferential arthrodesis is performed at the level of the osteotomy and posterior fusion is performed at all the instrumented levels. Following placement of the posterior graft, the surgical wound is closed by planes and a subcutaneous suction drain is installed.

\section{RESULTS}

The mean patient age at the time of surgery was 28 years (1 to 64 ). All the patients had important segmental kyphosis or significant reduction in lumbar lordosis, with mean angulation of $56.42^{\circ}$ $\left(2^{\circ}\right.$ to $\left.95^{\circ}\right)$. Prior to surgery, eight patients had signs of spinal distress (ASIA score ranging from A to D). Six patients did not present strength or sensitivity deficits (ASIA E). There was no neurological worsening and all patients with neurological deficits improved by at least one scale grade. The mean number of resected vertebrae was 2.57 (1 to 6) (Figure 2) and the mean number of instrumented levels was 6.14 (4 to 8). Mean residual deformity after correction in the sagittal plane was $20.28^{\circ}\left(-31^{\circ}\right.$ to $\left.61^{\circ}\right)$, with a mean correction rate of $64 \%$. (Figure 3) Computed tomography performed 6 months after surgery showed bone consolidation inside the titanium cage (Figure 4) in all patients except one, who is still in outpatient followup and remains asymptomatic. The most common complication was pleurotomy, observed in 6 patients, in whom intraoperative thoracic drainage was performed. (Table 1)

\section{DISCUSSION}

Historically, the surgical technique described by Hodgson et al., the Hong Kong procedure, ${ }^{12,13}$ alluding to the University of Hong Kong, the center where it was first performed, was used to treat vertebral tuberculosis surgically. The procedure consists of an

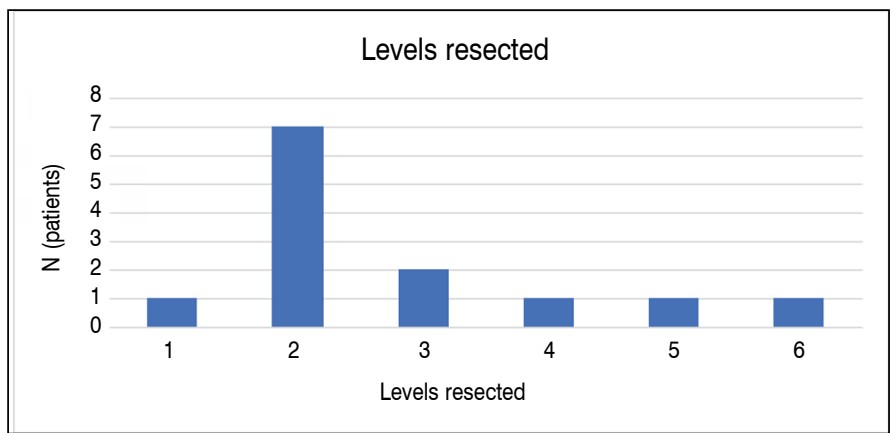

Figure 2. Number of levels resected by PVCR in the patients affected by tuberculous spondylodiscitis.

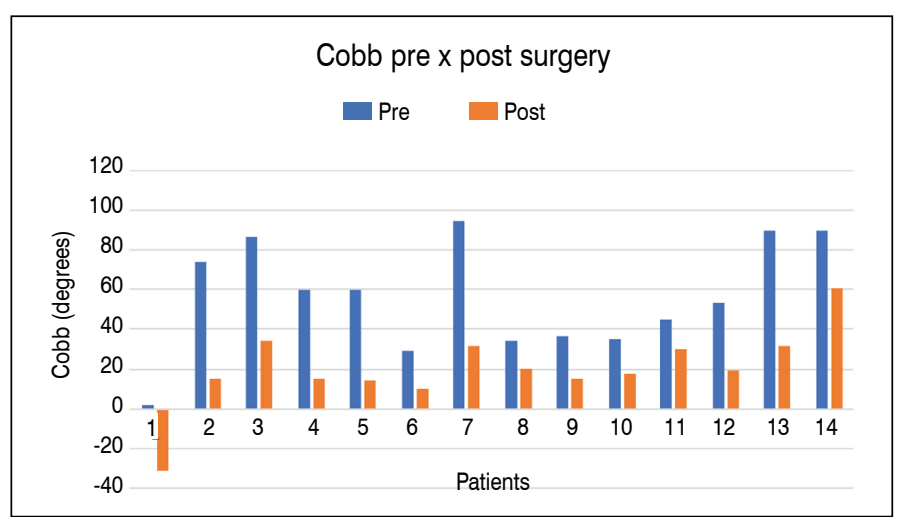

Figure 3. Analysis of correction in the sagittal plane in patients submitted to PVCR.

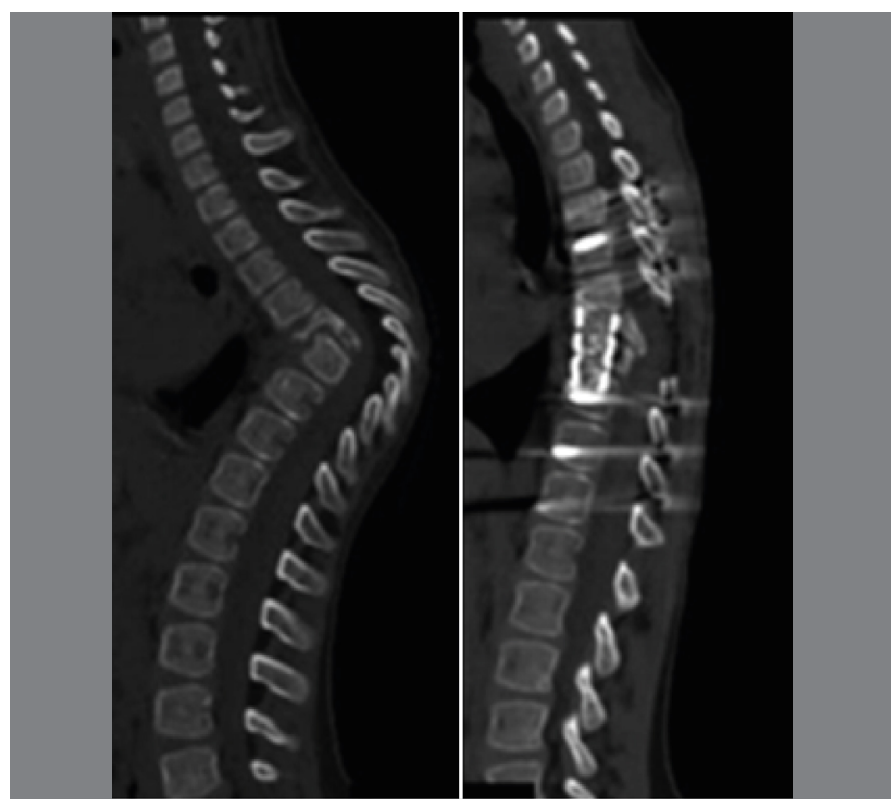

Figure 4. Preoperative and 6-month postoperative sagittal CT reconstructions, showing bone consolidation of the arthrodesis; images of the patient in Figure 1.

anterior approach to the spine, combined with ample debridement and anterior arthrodesis with the use of a tricortical graft. The works published by the University of Hong Kong showed the superiority of the procedure as compared to focal debridement, performed alone. As regards the rate of pseudoarthrosis and resolution of the disease, the technique described in 1956 has a satisfaction rate of $93 \%$. Our work presented a similar fusion rate of $92 \%$.

The combination of anterior approach instrumentation and posterior arthrodesis, although with no difference in the eradication of 
Table 1. Clinical and radiological results of vertebral tuberculosis correction by PVCR.

\begin{tabular}{|c|c|c|c|c|c|c|c|c|c|c|c|c|c|c|c|c|c|c|}
\hline $\begin{array}{l}\text { Medical } \\
\text { Records }\end{array}$ & Age & Sex & $\begin{array}{c}\text { Affected } \\
\text { levels }\end{array}$ & $\begin{array}{c}\text { Cobb } \\
\text { pre }\end{array}$ & $\begin{array}{l}\text { Cobb } \\
\text { post }\end{array}$ & $\begin{array}{c}\text { Franke } \\
\text { pre }\end{array}$ & $\begin{array}{c}\text { Franke } \\
\text { Post }\end{array}$ & $\begin{array}{c}\text { Instrumented } \\
\text { levels }\end{array}$ & Consol. & Bleed. & Location & ESR & CRP & ESR & CRP & $\begin{array}{l}\text { Blood cell } \\
\text { products }\end{array}$ & $\begin{array}{c}\text { Tissue } \\
\text { bank }\end{array}$ & Hemop. \\
\hline 351570 & 1 & $\mathrm{~F}$ & 4 & 74 & 15 & $E$ & $E$ & 4 & Ok & & \multicolumn{2}{|l|}{ T8-T11 } & & & & 1 & $S$ & $S$ \\
\hline 327212 & 32 & $\mathrm{M}$ & 2 & 60 & 15 & C & $\mathrm{E}$ & 6 & Ok & & \multicolumn{2}{|l|}{ T10-T11 } & & & & & $\mathrm{N}$ & $S$ \\
\hline 346207 & 10 & $\mathrm{~F}$ & 2 & 60 & 14 & $\mathrm{C}$ & $E$ & 6 & No & 1140 & \multicolumn{2}{|l|}{ T9-T10 } & & & & 2 & $\mathrm{~N}$ & $\mathrm{~N}$ \\
\hline 345616 & 29 & $\mathrm{M}$ & 2 & 29 & 10 & $E$ & $E$ & 6 & Ok & & \multicolumn{2}{|l|}{ T10-T11 } & & & & 2 & $\mathrm{~N}$ & $\mathrm{~N}$ \\
\hline 331077 & 1 & $\mathrm{~F}$ & 2 & 95 & 32 & $\mathrm{~B}$ & C & 6 & Ok & & T4-T5 & & & & & 1 & $\mathrm{~N}$ & $S$ \\
\hline 328921 & 58 & $\mathrm{M}$ & 3 & 35 & 18 & $E$ & $\mathrm{E}$ & 6 & Ok & & \multicolumn{2}{|c|}{ T11-T12-L1 } & 49 & & 0,5 & 5 & $\mathrm{~N}$ & $\mathrm{~N}$ \\
\hline 318047 & 4 & $\mathrm{M}$ & 2 & 45 & 30 & $\mathrm{C}$ & $\mathrm{E}$ & 7 & Ok & & \begin{tabular}{l|l} 
T5-T6 \\
\end{tabular} & 29 & 10 & & & 1 & $\mathrm{~N}$ & $\mathrm{~N}$ \\
\hline 334084 & 40 & $\mathrm{~F}$ & 3 & 53 & 19 & $\mathrm{~B}$ & $\mathrm{C}$ & 6 & Ok & & \multicolumn{2}{|c|}{ T8-T9-T10 } & & & & 1 & $\mathrm{~N}$ & $\mathrm{~S}$ \\
\hline 334681 & 24 & $\mathrm{M}$ & 6 & 90 & 32 & $E$ & $E$ & 8 & Ok & 2500 & \multicolumn{2}{|c|}{ T10-L3 } & & & & 4 & $\mathrm{~N}$ & $\mathrm{~N}$ \\
\hline 287282 & 5 & $\mathrm{~F}$ & 3 & 90 & 61 & $\mathrm{D}$ & $E$ & 5 & Ok & & \multicolumn{2}{|c|}{ T3-T4-T5 } & & & & & $\mathrm{N}$ & $\mathrm{N}$ \\
\hline
\end{tabular}

Consol.: Consolidation; Hemop.: Hemopneumothor.

infection, produced better results in reducing kyphosis and maintaining the reduction over the years. Schulitz et al. reported a loss of 12 degrees with the isolated anterior approach, ${ }^{14}$ while Rajasekaran et al. reported a loss of $22 \%$ in correction during follow-up. ${ }^{14}$ With the combined anterior and posterior approach, Moon et al. reported a loss of only 3 degrees. ${ }^{15}$ The rate of correction also is greater in association with the posterior approach. ${ }^{16}$ Qureshi et al. indicated $47 \%$ correction with the advent of this technique and only $9 \%$ with the isolated anterior approach. ${ }^{17}$

PVCR provides, through a single approach that is familiar to the spine surgeon, access to the anterior, middle, and posterior spines. This approach allows circumferential decompression of the spinal cord, a significant reduction in kyphotic deformity, and good preparation for interbody arthrodesis. ${ }^{18-20}$ Hassan et al. obtained 26 degrees of kyphosis correction via the isolated posterior approach, despite the longer surgical time. ${ }^{21}$ Zhou et al. reported a 68\% kyphotic deformity correction rate in tuberculosis. In comparison, our study showed a mean of 20 degrees and a rate of $64 \% .{ }^{22}$ Another important advantage of PVCR when compared to double access is to avoid the morbidity inherent in anterior access, as the patient with tuberculosis many times suffers from significant pulmonary and systemic impairment.

Zhou et al. reported that kyphoses with Cobb angles greater than 60 degrees are not good indications for the anterior approach due to the difficulty of access to the apex of the deformity. ${ }^{22}$ As demonstrated in studies of the anterior approach, thoracic spine deformities that involve multiple levels have higher failure and postoperative correction loss rates, which contributes to the choice of PVCR in cases of severe kyphotic deformity.

Despite excellent radiographic results, PVCR is a technically complex and challenging procedure, associated with a high rate of complications. Dorward and Lenke conducted a review and reported that the mean rate of neurological complications in performing PVCR was as high as $14.3 \%$, mainly explained by biomechanical instability during surgery. ${ }^{23,24}$ With the goal of preventing iatrogenic lesions of the spinal cord, the temporary rods must always be exchanged for new rods to ensure the mechanical integrity of the system and spinal stability. ${ }^{25}$ The postoperative use of thoracolumbosacral orthosis for 3 months in patients with resection of one or two vertebral segments and for 6 months in patients submitted to resection of three or more segments is also indicated. ${ }^{26}$ In our case series, no loosening of screws or rod breakage was observed, nor was there neurological worsening in any patient, and all who had deficit improved by at least one grade on the ASIA scale.

PVCR was applied to all cases in our study, including pediatric patients, as they satisfied the severe deformity criterion or had associated neurological deficit. It is important to perform pedicular instrumentation in these cases, despite the technical difficulty, to create effective post-osteotomy stabilization. According to Harms et al., pedicular instrumentation in very young children did not produce adverse effects to additional vertebral growth, which was comparable to the anteroposterior and craniocaudal growth of instrumented vertebrae and adjacent non-instrumented vertebrae. ${ }^{27}$

Correlating our results with those in the literature, PVCR is a safe and effective surgical indication in the treatment of severe kyphosis from tuberculosis in all age groups, with proven success in deformity correction, the maintenance of that correction, and in the bone consolidation rate, especially when the patient has involvement of the thoracic spine or of 2 or more vertebral levels.

\section{CONCLUSION}

Posterior vertebral column resection was shown to be a safe and effective option in the treatment of kyphosis from spinal tuberculosis.

All authors declare no potential conflict of interest related to this article.

CONTRIBUTION OF THE AUTHORS: Each author made significant individual contributions to this manuscript. PBLG and LECTS were the main contributors to the writing of the manuscript. PBLG, LECTS, AGCB, and LEPCAA performed the surgeries, followed up with the patients, and collected the clinical data. PBLG and LEPCAA evaluated the statistical analysis data. LECTS and AGCB conducted the bibliographical research, the manuscript review, and contributed to the intellectual concept of the study.

\section{REFERENCES}

1. World Health Organization. Guidelines for treatment of tuberculosis [Internet]. Geneva: World Health Organization; 2016 [Acesso em 27 Jul. 2015]. Disponível em: http://www.who.int/tb/publications/2010/9789241547833/en/

2. Ministério da Saúde do Governo Federal do Brasil - Sistema de Informação de Agravos de Notificação, atualizado em 29 de abril de 2019 [Acesso em?]. Disponível em: https://portalsinan.saude.gov.br/tuberculose

3. Ozvaran MK, Baran R, Tor M, Dilek I, Demiryontar D, Arinç S, et al. Extrapulmonary tuberculosis in non-human immunodeficiency virus- infected adults in an endemic region. Ann Thorac
Med. 2007;2(3):118-21. doi: 10.4103/1817-1737.33700

4. Jain AK. Tuberculosis of the spine: a fresh look at an old disease. J Bone Joint Surg Br. 2010;92(7):905-13. doi: 10.1302/0301-620X.92B7.24668

5. Sun L, Song Y, Liu L, Gong Q, Zhou C. One-stage posterior surgical treatment for lumbosacral tuberculosis with major vertebral body loss and kyphosis. Orthopedics. 2013;36(8):e108290. doi: 10.3928/01477447-20130724-28

6. Tuli SM. Results of treatment of spinal tuberculosis by" middle-path" regime. J Bone Joint Surg Br. 1975;57(1):13-23. 
7. Rajasekaran S, Shetty AP, Dheenadhayalan J, Reddy JS, Naresh-Babu J, Kishen T. Morphological changes during growth in healed childhood spinal tuberculosis: a 15-year prospective study of 61 children treated with ambulatory chemotherapy. J Pediatr Orthop. 2006;26(6):716-24. doi: 10.1097/01.bpo.0000230326.21707.71

8. A controlled trial of anterior spinal fusion and debridement in the surgical management of tuberculosis of the spine in patients on standard chemotherapy: a study in Hong Kong. $\mathrm{Br} \mathrm{J}$ Surg. 1974;61(11):853-66. doi: 10.1002/bjs.1800611102

9. Jain AK, Dhammi IK, Jain S, Mishra P. Kyphosis in spinal tuberculosis-prevention and correction. Indian J Orthop. 2010;44(2):127-36. doi: 10.4103/0019-5413.61893

10. Moon MS, Woo YK, Lee KS, Ha KY, Kim SS, Sun DH. Posterior instrumentation and anterior interbody fusion for tuberculous kyphosis of dorsal and lumbar spines. Spine (Phila Pa 1976). 1995;20(17):1910-6. doi: 10.1097/00007632-199509000-00013.

11. Wang Z, Yuan H, Geng G, Shi J, Jin W. Posterior mono-segmental fixation, combined with anterior debridement and strut graft, for treatment of the mono-segmental lumbar spine tuberculosis. Int Orthop. 2012;36(2):325-9. doi: 10.1007/s00264-011-1475-4

12. Suk SI, Kim JH, Kim WJ, Lee SM, Chung ER, Nah KH. Posterior vetebral column resection for severe spinal deformities. Spine (Phila Pa 1976). 2002;27(21): 2374-82. doi: 10.1097/00007632-200211010-00012

13. Hodgson AR, Stock FE, Fang HS, Ong GB. Anterior spinal fusion. The operative approach and pathological findings in 412 patients with Pott's disease of the spine. Br J Surg. 1960;48:172-8. doi: 10.1002/bjs. 18004820819

14. Schulitz KP, Kothe R, Leong JCY, Wehling P. Growth Changes of Solidly Fused Kyphotic Bloc After Surgery for Tuberculosis. Spine (Phila Pa 1976). 1997;22(10):1150-5. doi: 10.1097/00007632-199705150-00016

15. Rajasekaran S, Vijay K, Shetty AP. Single-stage closing-opening wedge osteotomy of spine to correct severe post-tubercular kyphotic deformities of the spine: a 3-year follow-up of 17 patients. Eur Spine J. 2010;19(4):583-92. doi: 10.1007/s00586-009-1234-z.

16. Moon M-S. Combined posterior instrumentation and anterior interbody fusion for active tuberculous kyphosis of the thoraco-lumbar spine. Curr Orthop. 1991;5(3):177-9. doi:10.1016/0268-0890(91)90039-3

17. Qureshi MA, Khalique AB, Afzal W, Pasha IF, Max Aebi. Surgical management of contiguous multilevel thoracolumbar tuberculous spondylitis. Eur Spine J. 2013;22(Suppl 4):618-23. doi: $10.1007 /$ s00586-012-2459-9
18. Wang Y, Zhang Y, Zhang X, Huang P, Xiao S, Wang Z, et al. A single posterior approach for multilevel modified vertebral column resection in adults with severe rigid congenital kyphoscoliosis: a retrospective study of 13 cases. Eur Spine J. 2008;17(3):361-72. doi: 10.1007/s00586-007-0566-9

19. Fukuta S, Miyamoto K, Masuda T, Hosoe H, Kodama H, Nishimoto H, et al. Two-stage (posterior and anterior) surgical treatment using posterior spinal instrumentation for pyogenic and tuberculotic spondylitis. Spine (Phila Pa 1976). 2003;28(15):E302-8. doi: 10.1097/01. BRS.0000083318.40123.5E

20. Kawahara N, Tomita K, Baba H, Kobayashi T, Fujita T, Murakami H. Closing-opening wedge osteotomy to correct angular kyphotic deformity by a single posterior approach. Spine (Phila Pa 1976). 2001;26(4):391-402. doi: 10.1097/00007632-200102150-00016

21. Hassan K, Elmorshidy E. Anterior versus posterior approach in surgical treatment of tuberculous spondylodiscitis of thoracic and lumbar spine. Eur Spine J. 2016;25(4):1056-63. doi: 10.1007/s00586-016-4451-2

22. Zhou T, Li C, Liu B, Tang X, Su Y, Xu Y. Analysis of 17 cases of posterior vertebral column resection in treating thoracolumbar spinal tuberculous angular kyphosis. J Orthop Surg Res. 2015;10:64. doi: 10.1186/s13018-015-0195-7

23. Dorward IG, Lenke LG. Osteotomies in the posterior-only treatment of complex adult spinal deformity: a comparative review. Neurosurg Focus. 2010;28(3):E4. doi: 10.3171/2009.12. FOCUS09259

24. Lenke LG, O'Leary PT, Bridwell KH, Sides BA, Koester LA, Blanke KM. Posterior vertebral column resection for severe pediatric deformity: minimum two-year follow-up of thirty-five consecutive patients. Spine (Phila Pa 1976). 2009;34(20):2213-21. doi: 10.1097/ BRS.0b013e3181b53cba

25. Xie J, Wang Y, Zhao Z, Zhang Y, Si Y, Li T, et al. Posterior vertebral column resection for correction of rigid spinal deformity curves greater than $100^{\circ}$. J Neurosurg Spine. 2012;17(6):540-51. doi: 10.3171/2012.9.SPINE111026.

26. Wang Y, Zhang YG, Zhang XS, Wang Z, Mao KY, Chen C, et al. Posterior-only multileve modified vertebral column resection for extremely severe Pott's kyphotic deformity. Eur Spine J. 2009;18(10):1436-41. doi: 10.1007/s00586-009-1067-9

27. Ruf M, Harms J. Pedicle Screws in 1- and 2-Year-Old Children: Technique, Complications, and Effect on Further Growth. Spine (Phila Pq 1973). 2002;27(21):E460-66. doi: 10.1097/00007632-200211010-00019 